\title{
EFEKTIVITAS MODEL PROBLEM BASED LEARNING (PBL) DISERTAI FISHBONE DIAGRAM (FD) UNTUK MEMBERDAYAKAN KEMAMPUAN MENGANALISIS
}

\author{
Pinkan Amita Tri Prasasti \\ Prodi PGSD FIP IKIP PGRI MADIUN \\ pinkan.amita@gmail.com
}

\begin{abstract}
The purpose of this study was to determine the effectiveness of a problem based learning model accompanied with Fishbone Diagram to empower the ability to analyse. This study was a quasi-experimental study. The study used a one-group pretest-posttest design. The population of the study was all students of grade $X$ of Public Senior High School 2 Karanganyar in the academic year of 2013/2014. Sample was taken using cluster random sampling technique with a sample of 36 students. The instrument used was questionnaire, observation sheets, interviews, and tests. The ability to analyze data was tested with the Wilcoxon test and calculated by $N_{\text {gain. }}$. The results showed the effectiveness of PBL module accompanied with FD, in which it had been successful in increasing the ability to analyse with a value of $N_{\text {gain }}$ of 0.71 and the result was significance at $p=0.000$, making the ability belong to "high" category. Based on the results of research and hypothesis testing, it can be concluded that PBL model with FD was effective in empowering the ability to analyseof the tenth graders of.
\end{abstract}

Keywords: Problem Based Learning (PBL), Fishbone Diagrams (FD), Ability to analyse

\begin{abstract}
Abstrak
Tujuan Penelitian ini adalah untuk mengetahui efektifitas model pembelajaran berbasis Problem Based Leraning disertai Fishbone Diagram untuk memberdayakan kemampuan menganalisis. Penelitian ini adalah penelitian kuasi eksperimen. Desain penelitian menggunakan one group pretest-posstest design. Populasi dalam penelitian adalah seluruh siswa kelas X SMA Negeri 2 Karanganyar Tahun Pelajaran 2013/2014. Teknik pengambilan sampel dilakukan secara cluster random sampling dengan pengambilan sampel sejumlah 36 siswa. Instrumen yang digunakan adalah angket, lembar observasi, wawancara dan tes. Data kemampuan menganalisis diuji dengan uji Wilcoxon dan dihitung dengan $N_{\text {gain. }}$. Hasil penelitian menunjukan bahwa efektivitas model berbasis $P B L$ disertai FD menunjukkan peningkatan dengan kategori tinggi dalam memberdayakan kemampuan menganlisis dengan perolehan $N_{\text {gain }} 0,71$ serta hasil signifikansi sebesar $p=0,000$. Berdasarkan hasil penelitian dan uji hipotesis dapat disimpulkan bahwa model PBL disertai FD efektif dalam memberdayakan kemampuan menganalisis siswa.
\end{abstract}

Kata Kunci: Problem Based learning (PBL), Fishbone Diagram (FD), Kemampuan Menganalisis 


\section{A. Pendahuluan}

Era abad 21 merupakan abad yang didominasi oleh berbagai pengetahuan yang mengutamakan pengembangan otak. Manusia memanfaatkan otak sebagai sumber daya berpikir, mengembangakan life skill atau kecakapan hidup maupun keterampilan khusus dalam memecahkan segala permasalahan global, tak terkecuali pada permasalahan pendidikan. Pendidikan yang sesuai dengan perkembangan abad 21 menurut Amir (2010), lebih mengandalkan pada pengembangan keterampilan yang meliputi, keterampilan berpikir, keterampilan pemecahan masalah, keterampilan berkomunikasi yang merupakan bagian dari keterampilan proses pembelajaran untuk mendukung optimalisasi pencapaian pendidikan khususnya pada pembelajaran sains.

Sains merupakan ilmu yang memberikan dampak positif bagi perkembangan siswa terutama untuk menjawab perkembangan abad 21. Toharudin (2011) menyatakan bahwa pembelajaran sains akan melatih siswa dalam meningkatkan kompetensi memahami masalah-masalah yang dihadapi oleh masyarakat modern yang bergantung pada teknologi dan kemajuan, serta perkembangan ilmu pengetahuan. Sains akan menghasilkan siswa yang berkualitas memiliki nilai, sikap dan keterampilan berpikir tingkat tinggi, sehingga menghasilkan siswa yang dapat berpikir kritis dalam menghadapi permasalahan.

Fakta pembelajaran menunjukkan rendahnya tingkat kecakapan berpikir tingkat $\mathrm{C} 4, \mathrm{C} 5$, dan C6 dengan didukung penelitian Tjalla (2010) yang menyatakan bahwa pembelajaran yang dominan di sekolah masih membelajarkan tingkat rendah yakni mengetahui, memahami dan menggunakan, belum mampu menumbuhkan kebiasaan berpikir menganalisis, mengevaluasi dan mencipta yakni suatu kemampuan esensi dari dimensi belajar. Pendidik sebagian besar belum merancang pembelajaran yang mengembangkan kemampuan berpikir kritisnya.

Penerapan kemampuan menganalisis pada pembelajaran sains dapat terlihat dari penilaian The Programme for International Student Assessment (PISA) adalah studi yang dikembangkan oleh beberapa negara maju di dunia yang menilai matematika dan sains. Kemampuan literasi sains siswa Indonesia berada pada peringkat ke-50 dari 57 negara. Skor rata-rata sains yang diperoleh siswa Indonesia adalah 393 dengan skor rata-rata tertinggi 563. Kompetensi siswa Indonesia dalam menganalisis masalah ilmiah lebih rendah $(-0,4)$, menjelaskan fenomena secara ilmiah lebih tinggi (1,1 poin), dan menggunakan fakta ilmiah lebih rendah $(-7,8)$. Sementara itu, pengetahuan siswa Indonesia tentang sains lebih 
rendah (-6,4). Data tersebut membuktikan bahwa proses pembelajaran sains masih belum optimal. Kemampuan siswa dalam menguasai pembelajaran sains melaui aspek menganalisis masalah menunjukkan nilai yang masih rendah.

Kemampuan menganalisis merupakan bagian dari kemampuan berpikir kritis yang menjadi salah satu aspek dari enam aspek lain meliputi interpretasi, kesimpulan, evaluasi, penjelasan, dan pengaturan diri. Aspek-aspek yang melandasi berpikir kritis memiliki sub indikator yang lebih terperinci teperinci (Facione, 2011). Pemilihan aspek menganalisis selain mengacu pada data yang ditemukan juga mempertimbangakan kefektivan tes yang disusun sebagai sarana pelatihan kemampuan berpikiri kritis, jika semua aspek digunakan dan dengan sub indikator yang banyak maka dikhawatirkan tes tidak berfungsi secara optimal dalam memberdayakan berpikir kritis. Hal ini dikarenakan setiap aspek hanya akan terwakilkan 1 atau 2 soal dengan mengacu pada keterbatasan waktu dalam penyelesaiannya, sehingga agar lebih efektiv dan efisien maka hanya menggunakan satu aspek dengan lebih mengembangkan sub indikator agar lebih terperinci.

Hasil observasi awal proses pembelajaran di SMA Negeri 2
Karanganyar melalui Standar Nasional Pendidikan (SNP), menunjukkan bahwa standar proses memiliki ketercapaian terendah dari standar lainnya $(83,83 \%)$. Rendahnya standar proses dibanding dengan standar yang lain tentunya dipengaruhi oleh lemahnya proses pembelajaran. Permasalahan lain adalah, siswa belum maksimal menggunakan kemampuan berpikir kritisnya khususnya kemampuan menganalisis terbukti dari kriteria soal yang diberikan belum banyak mengarah pada jenis soal $\mathrm{C} 4$, C5, dan C6 sehingga kemampuan siswa untuk mengembangkan kemampuan berpikir belum optimal.

Hasil lembar observasi awal yang dilakukan di kelas menyatakan bahwa penialian siswa atas keaktifan, motivasi belajar, kedisiplinan, penugasan, kemadirian dan interaksi sosial memiliki rata-rata sebesar 2,43 ini berarti komponen siswa dalam kegiatan proses pembelajran masuk pada kategori "Kurang Baik". Hasil observasi yang dilakukan pada guru meliputi komponen penguasaan materi, sistemtika penyajian, penerapan metode, penggunaan media, performance dan pemberian motivasi memiliki rata-rata 2,16 yang berarti masuk dalam kategori "Kurang baik". Kondisi umum yang ditemukan di kelas meliputi fungsi guru yang lebih dominan, siswa cenderung pasif. Siswa kurang sistematis dalam proses berpikir dan masih kesulitan dalam pengorganisasian materi terlihat pada catatan materi siswa yang kurang sistematis. Siswa belum terbiasa menggunakan teknik pengembangan 
kerja otak agar lebih memeper mudah dalam mengakomodir pemahaman terhadap materi sehingga mengakibatkan kurang optimalnya tingkat pemahaman siswa terhadap materi biologi yang diajarkan.

Pemberdayaan kemampuan menganalisis pada siswa dalam melaksanakan proses pembelajaran biologi dapat dilatih melalui pemilihan strategi, metode, maupun model yang tepat. Proses pembelajaran di SMA Negeri 2 Karanganyar belum mengoptimalkan penggunaan model pembelajaran yang sifatnya konstuktivistik dan tentunya mengacu pada Kurikulum 2013 yang meliputi Problem Based Learning, Inqury dan Project Based Learning. Pembelajaran lebih dominan ditekankan pada pembelajaran searah dari guru ke siswa, sehingga siswa cendeurung pasif.

Penggunaan model pada pembelajaran biologi mencakup beberapa materi yang membutuhkan analisis seperti pada materi pencemaran lingkungan. Materi pencemaran lingkungan berdasarkan data hasil pemetaan nilai UAN membuktikan bahwa materi tersebut khususnya di SMAN 2 Karanganyar termasuk kompetensi dasar (KD) yang belum tuntas karena nilai rata-rata $50 \%$. Karakteristik dari materi pencemaran lingkungan cenderung pada penguasaan analisis yang belum begitu dipahami oleh siswa sehingga nilai belum mencapai ketuntasan dan belum sepenuhnya sesuai dengan karakteristik materi. Siswa kurang terbiasa dalam menyelesaikan permasalahan guna memberdayakan kemampuan menganalisis sehingga belum mampu, mengidentifikasi dan menemukan solusi dari permasalahan.

Penggunaan model pada materi pencemaran lingkungan dapat dikembangkan dengan Problem Based Learning $(P B L)$ disertai Fishbone Diagram (FD) dengan model tersebut siswa akan dilatih memecahkan masalah yang berhubungan dengan materi. Pembelajaran $P B L$ adalah pembelajaran yang merangsang siswa untuk menganalisis masalah memperkirakan jawabann terhadap masalah.

FD (diagram tulang ikan karena bentuknya seperti tulang ikan) sering juga disebut Cause and Effect Diagram atau Ishikawa Diagram diperkenalkan oleh Kaoru Ishikawa, seorang ahli pengendalian kualitas dari Jepang. FD dapat membantu siswa menganalisis kemungkinan penyebab suatu masalah pada materi pembelajaran yang diberikan. Siswa dilatih mengkonstruk pemikiran untuk merangsang pengetahuan, mempromosikan diskusi, dan dapat mendidik tentang proses atau masalah. Siswa belajar melalui permasalahan praktis yang berhubungan dengan materi pembelajaran sebagai suatu konteks bagi siswa untuk belajar tentang cara menganalisis dalam memecahkan masalah. 
Berdasarkan uaraian di atas dilakukan penelitian bejudul: "Efektivitas Model Problem Based Learning disertai Fishbone Diagram pada Materi Pencemaran Lingkungan untuk Memberdayakan Kemampuan Menganalisis".

\section{B. Metode Penelitian}

Berdasarkan masalahmasalah yang akan dipelajari, maka penelitian ini menggunakan metode eksperimen semu (Quasi exsperimental researchDesain yang digunakan dalam uji coba lapangan ini adalah One Group Pretest Postes Design dengan menggunakan satu kelas eksperimen (memakai model berbasis $P B L$ disertai $F D$ ) dengan pemberian pretest dilanjutkan dengan pemberian posttest pada kelompok tersebut (Sugiyono, 2010). Rancangan penelitian dapat dilihat pada Tabel 1.

Tabel 1. Rancangan Penelitian One Group Pretest Posttest Design

\begin{tabular}{llll}
\hline Kelompok & $\begin{array}{r}\text { Pre } \\
\text { test }\end{array}$ & $\begin{array}{r}\text { Treat } \\
\text { ment }\end{array}$ & $\begin{array}{c}\text { Post } \\
\text { test }\end{array}$ \\
\hline Eksperimen $\mathrm{P}_{1}$ & $\mathrm{X}_{1}$ & $\mathrm{O}_{2}$
\end{tabular}

Keterangan:

$\mathrm{P}_{1}$ : Tes awal yang diberikan kepada kelompok eksperimen.

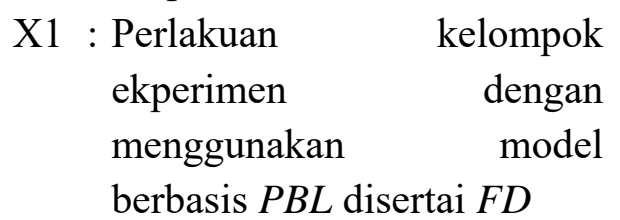

$\mathrm{O}_{2}$ : Tes akhir yang diberikan kepada kelompok eksperimen.

Teknik pengambilan sampel menggunakan cluster random sampling yang terdiri dari satu kelas. Yaitu kelas $\mathrm{X}$ sains 1 SMA Negeri 2 Karanganyar sebagai kelas eksperimen dengan membandingkan hasil pretest dan Posttest. Populasi dalam uji coba lapangan skala ini adalah semua siswa Kelas X SMA Negeri 2 Karanganyar. Variabel bebas adalah model $P B L$ disertai FD. Variabel terikat adalah kemampuan menganalisis.

Teknik pengumpulan data yang digunakan dalam penelitian ini menggunakan metode tes dan metode non tes. Metode tes digunakan untuk memperoleh data kemampuan menganalisis dan hasil belajar kognitif, Pertanyaan dalam tes dapat berupa tes tertulis maupun lisan. Tes yang akan digunakan dalam penelitian ini adalah kemampuan menganalisis dan tes pencapaian hasil belajar menyangkut penguasaan materi dan kemampuan akhir para peserta didik setelah melalui proses pembelajaran (Darmadi, 2011). Tes yang digunakan berupa tes objektif yaitu berntuk pilihan ganda dan essay.

Metode Non tes menggunakan teknik dokumentasi, observasi, wawancara dilakukan dengan mengumpukan data, mengambil catatancatatan dan menelaah dokumen yang ada yang dimiliki kaitan dengan objek penelitian (Riduwan, 2004). Data yang dikumpulkan dengan teknik ini adalah data nilai siswa (nilai ulangan harian 
yang meliputi nilai pada ranah kognitif) pada ulangan-ulangan sebelumnya.

Teknik observasi digunakan untuk mengukur hasil belajar meliputi kognitif, afektif dan psikomotor, selain itu metode observasi juga digunakan untuk mengukur keterlaksanaan sintak dari strategi pembelajaran yang dilaksanakan yaitu model pembelajaran $\quad P B L$ disertai Fishbone Diagram . Data tersebut digunakan sebagai penguat bahwa model pembelajaran ini telah diterapkan di kelas. Observasi ini dilakukan pada saat proses kegiatan itu berlangsung dengan bantuan observer yang berugas mengamati dan menilai segala bentuk kegiatan dan aktivitas siswa saat pembelajaran berlangsung.

Instrumen

penilaian

kemampuan menganalisis berupa tes pilihan ganda, kemampuan kognitif yang digunakan berupa tes objektif, sedangkan untuk tes objektif sebelum digunakan untuk mengambil data penelitian, diujicobakan terlebih dahulu untuk mengetahui kualitas soal. Kelayakan instrumen yang digunakan dalam penelitian ini maka dilakukau uji kelayakan yang diuji dengan statistik meliputi uji validitas, uji reliabiitas, uji pembeda soal, uji indeks kesukaran.

Tujuan penelitian ini adalah untuk mengetahui taraf signifikansi pengaruh pembelajaran menggunakan model berbasis PBL disertai FD pada materi terhadap kemampuan menganalisis siswa. Persyaratan data statistik agar dapat diuji menggunakan paired $t$ - test adalah sebaran data harus normal dan homogen. Untuk itu sebelumnya perlu dilakukan uji prasyarat analisis yaitu uji normalitas dan uji homogenitas dan jika data tidak memenuhi syarat yang berarti data tidak normal atau data tidak homogen maka uji yang digunakan adalah uji non parametrik dengan menggunakan uji Wilcoxon. Namun sebelum di uji efektivitas terlebih dahulu dihitung peningkatan Kemampuan menganalisis siswa dengan teknik normalized gain atau sering disebut gain score. Analisis data yang digunakan dalam penelitian ini adalah uji Wilcoxon karena data tidak memenuhi persyaratan pada uju prasayarat sehingga harus menggunakan jenis uji statistik nonparametrik. Teknik analisis data ini digunakan untuk menguji hipotesis yang telah dikemukakan di depan.

Uji prasyarat dilakukan sebelum uji kesetimbangan dengan uji-t, uji prasayarat menggunakan uji Kolmogorv-Smirnov yang digunakan untuk uji normalitas sedangkan pada uji homogenitas digunakan uji dari Levene's.

Uji normalitas digunakan untuk mengetahui apakah sampel penelitian berasal dari populasi yang normal atau tidak. Untuk mengevaluasi $\mathrm{H}_{\mathrm{o}}$ yang menyatakan data tidak mengikuti distribusi normal digunakan uji 
normalitas menggunakan uji Kolmogorv-Smirnov pada program SPSS 18 dengan menentukan taraf signifikansi $\mathrm{p}(p$-value $)=0,05$.

Uji homogenitas untuk menguji apakah sampel penelitian berasal dari populasi yang homogen. Untuk mengetahui homogenitas variansi digunakan uji Levene-Test. Tes ini mengasumsikan bahwa sampel uji yang berbeda berasal dari populasi yang sama meskipun memiliki mean berbeda, akan tetapi memiliki variansi sama.

Pegujian hipotesis menggunakan Uji Wilcoxon. Uji Wilcoxon merupakan uji non parametrik uji beda dua sampel berpasangan namun mengalami perlakuan yang berbeda.

\section{Hasil Penelitian}

Hasil uji efektivitas dari produk modul berbasis $P B L$ disertai FD diperoleh dari data kemampuan menganalisis melaui uji hipotesis dan nilai peningkatan gain ternormalisasi $\left(N_{\text {gain }}\right)$.Hasil uji hipotesis data kemampuan menganalisis disajikan pada Tabel 2 Hasil uji Gain dan Ngain kemampuan menganalisis disajikan pada Tabel.3. Berdasarkan hasil penelitian dapat dibuat histogram rata-rata perbandingan kemampuan menganalisis pretest dan nilai posttest seperti pada Gambar.1 dan perbandingan persentase penilain aspek menganalisis pada Gambar 2.

Tabel.2 Hasil Uji Hipotesis Kemampuan Menganalisis

\begin{tabular}{|c|c|c|c|c|}
\hline Uji & Jenis Uji & Hasil & Keputusan & Kesimpulan \\
\hline Normalitas & $\begin{array}{l}\text { Kolmogorof- } \\
\text { Smirnov }\end{array}$ & $\begin{array}{l}\text { Sig pretest }=0,200 \\
\text { Sigposttes } \mathrm{t}=0,055\end{array}$ & Ho diterima & Data normal \\
\hline Homogenitas & Levene's test & Sig 0.019 & Ho ditolak & $\begin{array}{l}\text { Data tidak } \\
\text { homogen }\end{array}$ \\
\hline $\begin{array}{l}\text { Hasil Pretes- } \\
\text { Postes }\end{array}$ & Wilcoxon & $\begin{array}{l}\mathrm{t}_{\text {hitung }}= \\
-5,426 \\
\mathrm{p}=0,000\end{array}$ & Ho ditolak & $\begin{array}{l}\text { Hasil tidak } \\
\text { sama (ada } \\
\text { beda) }\end{array}$ \\
\hline
\end{tabular}

Tabel. 3 Hasil uji gain dan $N_{\text {gain }}$ Kemampuan Menganlisis

\begin{tabular}{cccc}
\hline \multirow{2}{*}{ Jenis data } & \multirow{N}{*}{\begin{tabular}{c}
\multicolumn{2}{c}{ Mean } \\
\cline { 3 - 4 }
\end{tabular}} & Gain & $N_{\text {gain }}$ \\
\hline $\begin{array}{c}\text { Kemampuan } \\
\text { Menganalisis }\end{array}$ & 36 & 26,11 & 0,71 \\
\hline
\end{tabular}




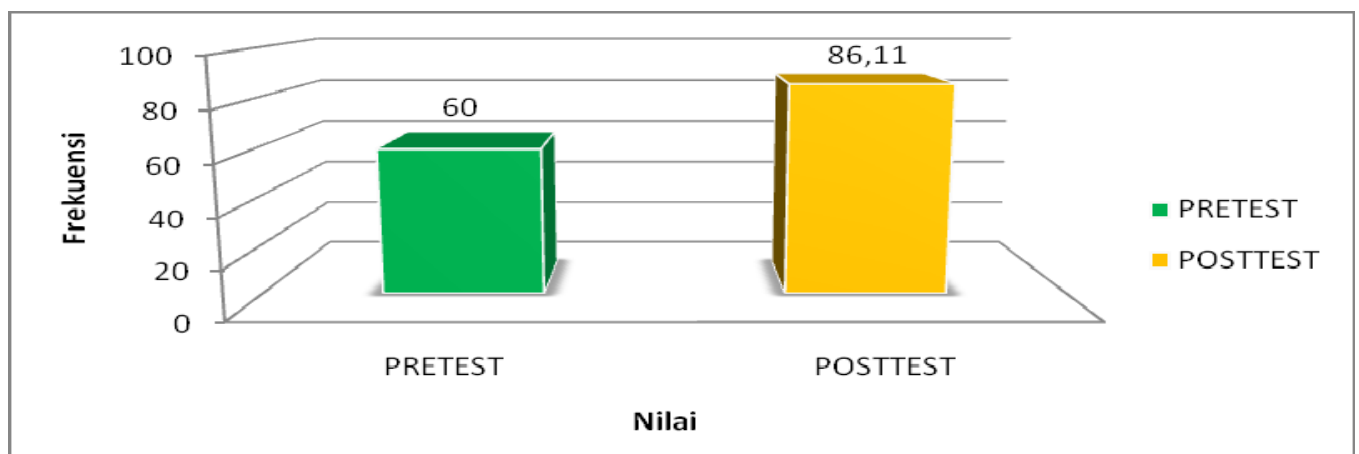

Gambar.1 Histogram Perbandingan Nilai Kemampuan Menganalisis

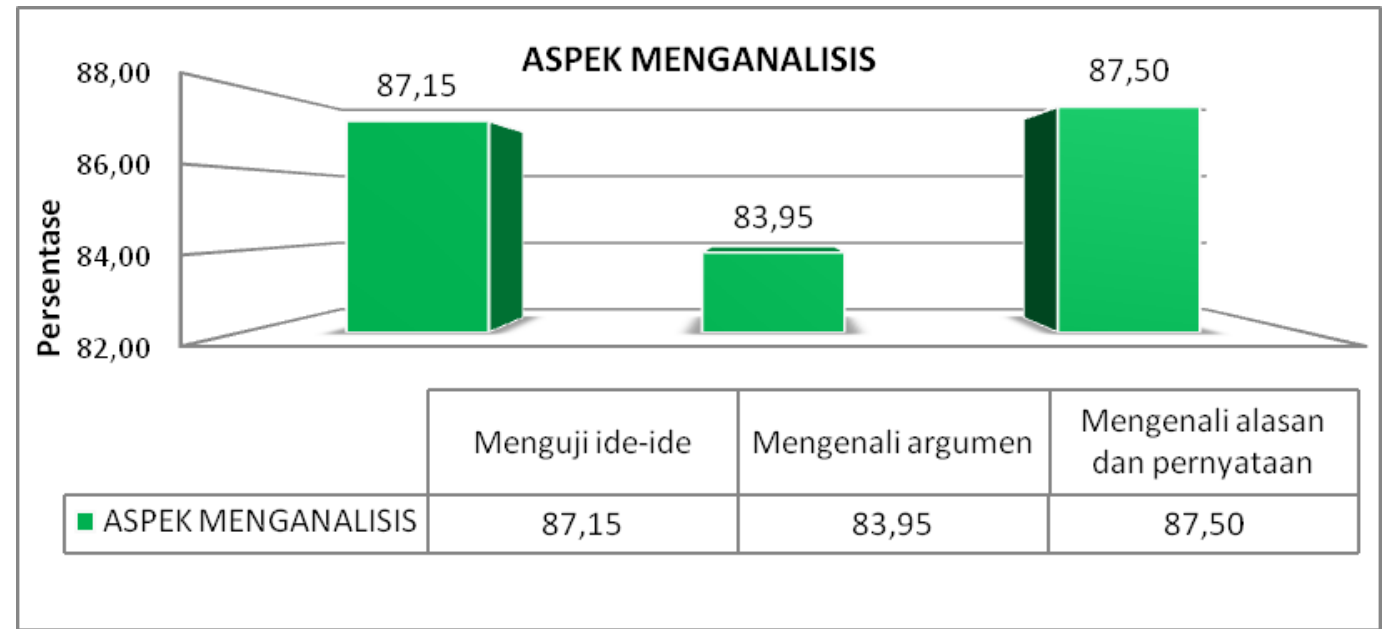

Gambar. 2 Histogram Perbandingan Persentase Penilaian Aspek Kemampuan Menganalisis

Hasil uji menunjukkan nilai kemampuan menganalisis memiliki peningkatan $N_{\text {gain }}$ berdasarkan rentang nilai yang tidak terlalu jauh kriteria Hake (1998) hasil masing-masing aspek berada pada kemampuan menganalisis siswa kisaran $80 \%$. Perolehan nilai tertinggi mengalami peningkatan dari hasil diperoleh pada aspek mengenali alasan pretest dan posttest yang masuk dalam kriteria peningkatan kategori "Tinggi". Kemampuan menganalisis diukur berdasarkan aspek penyususnnya yaitu terdiri dari 3 aspek meliputi menguji ideide, mengenali argument, mengenali alasan dan pernyataan. perolehan persentase penilaian masing-masing aspek penyusun dan pernyataan dengan persentase sebesar $87,50 \%$ sedangkan terendah pada aspek mengenali argumentargument sebesar 83,95\%, dan aspek menguji ide-ide sebesar $87,15 \%$.

\section{Pembahasan}

Berdasarkan hasil penelitian aspek tertinggi adalah pada aspek mengenali alasan dan pernyataan pada 
aspek ini siswa terlatih untuk mengenali hubungan inferesial yang diharapkan dan yang sesungguhnya antara pernyataan dengan alasan yang menjadi landasan untuk mengekspresikan keyakinan, penilaian, pengalaman, alasan dan informasi maupun pilihan (Facione, 2011). Siswa merasa lebih mudah ketika mengungkapkan alasan-alasan dari pada mengenali argument maupun menguji ide karena alasan merupakan pendapat langsung yang diberikan siswa ketika memahami dan mendapati suatu pernyataan. Siswa akan cenderung berpikir menganalisis menggunakan alasan-alasan yang tepat untuk sesuai dengan pemikirannya. Aspek terendah ada pada mengenali argument hal ini dikarenakan pada pengaplikasiannya penyususnnya soal pada asek ini dengan melibatkan argument-argument yang masing-masing argument memiliki kriteria yang mirip sehingga siswa kemungkinan kurang maksimal ketika harus mengenali argument yang sesuai dengan hasil analisis mereka. Proses pembelajaran juga memiliki peran penting dalam memebntuk siswa melatih kemampuan menganalisisnya, selama proses pembelajaran siswa dilatih untuk menggunakan segala daya nalar pikirnya untuk berusaha menganalisis permsalahan yang ada. Siswa menjadi terbiasa berpikir sehingga akan lebih mudah ketika menegrjakan soal terbukti dengan persentase dari masing-masing aspek yang berada pada kisaran $80 \%$. Inch, et.al, (2006) menyatakan bahwa kemampuan menganalisis diperlukan untuk peneyelidikan mengeksplorasi situasi, fenomena, pertanyaan atau masalah untuk menyusun hipotesis atau konklusi yang memadukan semuan informasi yang dimungkinkan dan dapat diyakini kebenarannya. pembelajaran yang mengembangkan kegaiatan percobaan memfasilitasi siswa untuk mampu mengembangkan kemampuan berpikir menganalisis.

Kenaikan nilai dari kemampuan menganalisis siswa ini tentunya tak luput dari peran Modul $P B L$ disertai FD. Kemampuan menganalisis merupakan bagian dari kemampuan berpikir kritis menurut Facione (2011). Berkaitan dengan keterampilan berpikir. Liliasari (2001), menyatakan bahwa model pembelajaran $\quad P B L \quad$ mampu meningkatakan keterampilan berpikir konseptual yang tinggi dengan pemberian masalah-masalah autentik yang ada disekitarnya. Menurut Akinoglu (2006) Peningkatan kemampuan berpikir dapat tercapai karena Modul $P B L$ disertai $F D$ mampu mengolah pola belajar siswa dari penerima informasi secra pasif menjadi penerima yang aktif, pembelajaran yang bebas dan pemecahan masalah. Penekanan program pendidikan dari kebiasaan mengajar menjadi belajar yang memungkinkan siswa untuk belajar 
hal-hal baru dengan mencari solusi dengan cara memecahkan permasalahan.

Model berbasis $P B L$ disertai $F D$ memeilliki efektivitas tinggi memeberdayakan kemampuan menganalisis sesuai dengan tahapan dalam model pembelajaran menekankan siswa menemukan sendiri konsep yang dipelajari, hal ini sejalan dengan teori belajar Jean Piaget bahwa siswa aktif mengkonstruksi secara terus menerus, sehingga terjadi pemahaman konsep ilmiah. Tahap $P B L$ mulai dari mengorientasikan masalah telah mengajarkan siswa untuk mulai berproses yang diawali dengan pemberian wacana dan gambar yanga akan membuat siswa untuk mencari sumber permasalahan dan penyebabnya. Siswa dalam menemukan konsep pembelajaran melakukan tahap penyelidikan yang diperoleh dari hasil rumusan masalah maupun hipotesis, selama proses penyelidikan siswa diharapkan mampu mengkonstruk sendiri pengetahuan dan menemukan konsep-konsep berdasarkan pengalaman langsung. Bruner terkenal dengan metode penemuannya, yang dimaksud dengan penemuan disini adalah siswa menemukan kembali, bukan menemukan sesuatu yang baru. Kaitannya dengan belajar, Bruner memandang belajar penemuan sesuai dengan pencarian pengetahuan secara aktif oleh manusia, berusaha sendiri untuk mencari pemecahan masalah serta didukung oleh pengetahuan yang telah ada, menghasilkan pengetahuan yang lebih bermakna.

Penggunaan model berbasis $P B L$ disertai $F D$ efektif memberdayakan kemampuan menganalisis dipengaruhi oleh pengetahuan awal siswa mengenai permasalahan lingkungan yang sering siswa temui sejalan dengan teori Ausubel yang berkaitan dengan belajar bermakna yaitu proses belajar dimana informasi baru dihubungkan dengan struktur pengertian yang sudah dipunyai seseorang yang sedang belajar. Tahap mengorientasikan siswa terhadap masalah merupakan tahapan $P B L$ yang didukung dengan teori Ausubel, siswa diberikan permasalahan yang berupa wacana berkaitan dengan kehidupan sehari-hari yang sering dialami siswa dan hal-hal baru yang kemungkinan jarang siswa temui. Hal ini akan berdampak bagi siswa dengan mengaitkan kemampuan kognitif awal yang dimiliki siswa melalui apersepsi yang diberikan oleh guru yang berfungsi mengaktifkan kembali pengetahuan awal sebelum siswa menerima konsep maupun pengetahuan baru yang akan membantu otak untuk membangun peta konseptual yang lebih baik

Pembelajaran dengan menggunakan model $P B L$ disertai $F D$ dilakukan dengan menggunakan kelompok. Siswa dikelompokkan secara heterogen agar kemampuan interaksi soasial akan muncul dan memunculkan 
kebiasaan sikap bekerja sama dengan teman. Melaui kerja kelompok siswa menjadi lebih mudah dalam berbagi pengetahuan dan bersama-sama saling membantu menemukan konsep, hal ini sejalan dengan teori Vigotsky yang menekankan pentingnya interaksi sosial dengan orang lain yang mempunyai pengetahuan yang lebih baik dan sistem secara kultural telah berkembang dengan baik Konsep lain yang berkaitan dengan interaksi sosial di kelas maupun di luar kelas adalah scaffolding , menurut Bruner scaffolding merupakan suatu proses untuk membantu siswa menuntaskan masalah tertentu melampaui kapasitas perkembangannya melalui bantuan guru, teman atau orang lain yang memiliki kemampuan lebih.

$$
\text { Adanya peningkatan }
$$

kemampuan menganalisis ini menunjukkan bahwa pembelajaran dengan menggunkan modul $P B L$ disertai FD ynag dalam aplikasinya menggunakan kegiatan eksperimen dalam memecahkan permasalahan yang melibatkan siswa dalam aktivitas pembelajaran yang memerlukan keterampilan berpikir menganalisis yang lebih tinggi sehingga siswa mampu mengembangan pikiran kritisnya, sesuai yang dikemukakan oleh Liliasari (2000) bahwa keterampilan berpikir selalu berkembang dan dapat dipelajari.
Selama proses pembeljaran pengembangan kemampuan berpikir menganalisis lebih melibatkan siswa sebagai pemikir daripada seorang yang belajar.

Model PBL disertai FD membantu siswa untuk belajar mandiri dan mengembangkan kemampuan berpikir kritis khususnya kemampuan menganalisis karena proses pembelajaran yang menekankan siswa untuk menganalisis akar masalah. Menurut Adnan (2011) PBL adalah kelas student centered yang memberikan siswa kesempatan untuk menemukan pengetahuan dalam cara yang berarti. Melalui $P B L$, siswa dapat pergi ke sumber luar selain apa yang tersedia di lingkungan kelas (Gurell, Kuo \& Walker 2010). Siswa dalam program $P B L$ lebih mungkin untuk lulus dan melakukannya dalam waktu kurang dari siswa dalam kurikulum yang lebih tradisional. Menghafal fakta dan informasi seperti di kelas tradisional bukan cara terbaik untuk belajar. Gaya kelas juga perubahan dalam kelas berbasis penyelidikan tidak lagi lingkungan yang kelas diatur oleh pelajaran yang pendek, tetapi diperintah oleh pelajaran yang saling berhubungan yang membantu siswa mengembangkan keterampilan menganalisis yang diperlukan untuk penyelidikan, kemudian memungkinkan mereka untuk memanfaatkan keterampilan-keterampilan dalam pemecahan masalah (Haghparast et.al, 2007).

$P B L$ juga mampu mengembangkan kemampuan berpikir 
kritis memfasilitasi siswa untuk mempertajam kemampuan menganalisis khususnya pada permasalahan yang diberikan melalui tahap-tahap yang menjadi penyusunnya. Hyerle (2012) berpendapat bahwa dengan pengembangan kerja otak melalui pengilustrasian maslah dengan menggunkan diagram memungkinkan siswa untuk memiliki kapasitas yang lebih mendalam untuk melihat, mengubah, membayangkan dan meningkatkan kemampuan berpikir dalam menganalisis permasalahn. Model berbasis $P B L$ disertai $F D$ akan membantu siswa untuk meningkatkan daya nalar berpikir dengan mengoptimalkan kerja otak melalui pemetaan pemikiran yang diasarkan pada pemberian masalah dengan mengilustrasikan masalah.

Peningkatan kemampuan

berpikir kritis khususnya kemampuan menganalisis yang dialami siswa setelah proses pembelajaran disebabkan siswa telah diarahkan secara aktif mengembangkan kemampuan menganalisis melalui kegiatan ekperimen dan pengamatan secara langsung. Selain itu, temuan ini juga menguatkan pengaruh praktikum dalam mengembangkan kemampuan berpikir kritis (Akhyani,2008). Dampak dari peningkatan kemampuan menganalisis yang merupakan bagian dari berpikir kritis terlihat dari kemampuan siswa yang mengajukan pertanyaan maupun mampu menjawab dengan jawaban yang tak terduga bahkan memunculkan solusi-solusi yang bervariasi. Menurut Kronberg \& Griffin (2000) peningkatan kemampuan berpikir dapat dilihat dari kemampuan menjawab pertanyaan terbuka dengan banyak alternatif jawaban benar dan pada akhirnya mampu meningkatkan kemampuan berpikir kritis berupa peningkatan pemahaman keaplikasi, sintesis, analisis serta menjadikan siswa sebagai pembelajar mandiri.

Berdasarkan indikator-indikator yang diteteapkan sebagai dasar penilaian kemampuan menganalisis siswa maka dengan bantuan model $P B L$ disertai $F D$ siswa memiliki kemampuan untuk mampu memisahkan materi atau informasi kedalam bagian-bagaian yang perlu, mencari hubungan antara bagianbagiannya, mengenal komponenkomponennya, bagaimana komponenekomponen itu berhubungan dan terorganisasikan. Beberapa komponen tersebut dapat terlatihkan dengan bantuan FD yang merupakan teknik dalam mengilustrasikan masalah sejalan dengan pendapat Hindri (2012) menyatakan bahwa dibutuhkan teknik mengilustrasikan masalah dalam suatu diagram atau gambar yang sering dinamakan causal map agar proses menganalisis masalah menjadi lebih mudah.

$\begin{array}{lll}\text { Hyerle } & \text { et al., } & \text { (2012) } \\ \text { berpendapat } & \text { bahwa } & \text { dengan } \\ \text { pengembangan } & \text { kerja otak } & \text { melalui }\end{array}$


pengilustrasian maslah dengan menggunkan diagram memungkinkan siswa untuk memiliki kapasitas yang lebih mendalam untuk melihat, mengubah, membayangkan dan meningkatkan kemampuan berpikir dalam menganalisis permasalahn. Pengembangan produk Modul berbasis $P B L$ disertai $F D$ akan membantu siswa untuk meningkatkan daya nalar berpikir dengan mengoptimalkan kerja otak melalui pemetaan pemikiran yang diasarkan pada pemberian masalah dengan mengilustrasikan masalah

\section{E. Kesimpulan dan Saran}

Model $P B L$ disertai FD terbukti memiliki efektivitas untuk memberdayakan kemampuan menganalisis diperoleh dari penilaian $N_{\text {gain }}$ memiliki nilai 0,71 yang berarti memiliki peningkatan dengan kategori "Tinggi". Setelah dilakukan uji secara statistik diperoleh adanya perbedaan kemampuan menganalisis siswa, sebelum dan setelah diterapkan model berbasis PBL disertai FD dengan hasil $p=0,000$.

Berdasarkan hasil penlitian maka peniliti meyarankan penerapan model PBL disertai FD ini menjadi rujukan dalam mengembangkan pembelajaran yang inivatif dan kretif, guru lebih aktif dan termotivasi untuk mengaplikasikan model-model pembelajaran lain yang sesuai dengan tujuan pembelajaran.

\section{Daftar Rujukan}

Akinaglu, O. \& Tandogan, R.O.2007. The Effect of Problem Based Active Learning of Student Academic Achievment, attitude and Concept Learning. Eurasia Journal of Mathematics, Science \& Technology Education, vol. 3, no. 1, hlm. 71-81.

Amir, Tufiq.2010. Inovasi Pendidikan Melalui Problem Based Learning. Jakarta: Kencana

Arends, R.I, \& Klicher, Ann. 2010. Teaching for Student Learning Becoming an Accomplished Teacher. New York: Taylor \& Francis.

Arikunto, Suharsimi. 2010. DasarDasar Evaluasi Pendidikan. Yogyakarta: Bumi Aksara.

Bigbee, A.F., Curtiss, J.A., Litwin, L.S. \& Harkin, M.T. 2010. MultiAgency C2 Experiment Lifecycles: The Collaborative Experimentation Environment as a Case Study. The International C2 Journal, vol. 4, no. 3, hlm. 128.

Dimopoulos, I.D., Stefanos, P \& John, D.P. 2009. Planning Educational Activities and Teaching Strategies On Constructing a Conservation Educational Module. International Journal of Environmental \& Science Education, vol. 4, no. 4, hlm. 351-364. 
Doggett, A.M. 2005. Root Cause Analysis: A Framework for Tool Selection. QMJ, vol.12, no. 4, hlm. 34-45.

Ergul, E., Simsekli, Y., Calis, S., Ozdilek, Z., Gocmencelebi, S., Sanli, M. 2011. The Effects Of Inquiry-Based Science Teaching On Elementary School Students' Science Process Skills And Science Attitudes. Bulgarian International Journal of Science and Education Policy (BJSEP), vol. 5, no. 1, hlm. 48-52.

Erick de Graaff. \& A. Kolmos. 2003. Characteristics of Problem-Based Learning. International. Journal. Enginering Education, vol. 19 , no. 5, hlm. 657-662.

Haghparast, N., Sedghizadeh, PP., Shuler, CF., Ferati, D \& Christersson, C. (2007). Evaluation of Students and Faculty Perceptions of the PBL Curriculum at two dental schools from a student perspective: A Cross-sectional survey', European Journal of Dental Education, vol. 11, no. 14 , hlm. 22 .

Hashemi, S.A. 2011. The Use Of Critical Thinking In Social Science Textbooks Of High School: A Field Study Of Fars Province In Iran .International Journal of Instruction, vol. 4, no. 1, hlm. 64-78.
Hindri, Asmoko. 2012. Teknik Ilustrasi Masalah-Fishbone Diagram. Balai Diklat Kepemimpinan, Pusdiklat Pengembangan SDM, BPPK: Magelang

Hyerle, D.N. \& Larry, A. 2012. Peta Pemikiran (Thinking Maps). Jakarta: Permata Puri Media.

Inch, E. S. 2006. Critical thinking and Comunication: The use of reason in Argument. $5^{\text {th }}$ Ed. Boston: Person education, Inc.

Kronberg, J.K \& Griffin. 2000. Analysis Problem A Means to Developing Student Critical Thinking: Pushing the Boundaries of Higher-Oder Thinking. Journal College Science Teacher, vol. 24, no. 5, hlm. 348-352.

Lawson. AE. 2007. Science Teaching and Development Thinking. California: Wordsworth Pub.Co.

Liliasari. 2000. "Pengembangan Keterampilan berpikir Kritis untuk Mepersiapkan Calon Guru IPA Memasuki Era Globalisasi”. Makalah Seminar Nasional Pengembangan Pendidikan MIPA di Era Globalisasi.

Riduwan. 2004. Metode dan Teknik Menyusun Tesis. Bandung: Alfabeta.

Sugiyono. 2010. Metode Penelitian Pendidikan Pendekatan Kuantitatif Kualitatif dan R\&D. Bandung : Alfabeta.

Tague, N.R. 2005. The Quality Tool Box, Second Edition. Milwake: ASQ Quality Press. 
236 | Premiere Educandum, Volume 5 Nomor 2, Desember 2015, 223 - 236

Thompson, Claudatte . 2011.

Critical Thinking across the

Curriculum: Process over

Output. International

Journal of Humanities and

Social Science, vol. 1, no. 9, hlm. 1-7.

Tjalla. 2010. Hubungan Antara Self-Regulated Leraning dengan Kemampuan Memecahkan Masalah.

Artikel fakultas Psikologi Universitas Gunadarma. 